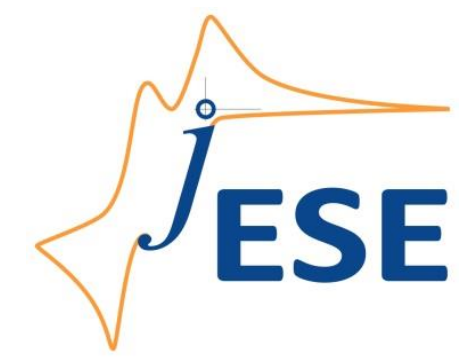

Open Access: ISSN 1847-9286

www.jESE-online.org

Original scientific paper

\title{
Revised Pourbaix diagrams for the vanadium - water system
}

\author{
Igor Povar ${ }^{1,2, 凶}$, Oxana Spinu², Inga Zinicovscaia ${ }^{1,2,3}$, Boris Pintilie ${ }^{2}$, Stefano Ubaldini ${ }^{4}$ \\ 1 Institute for Nuclear Research, Joliot-Curie Str., 6, 141980, Dubna, Russia \\ ${ }^{2}$ Institute of Chemistry, 3 Academiei str., MD 2028, Chisinau, Republic of Moldova \\ ${ }^{3}$ Horia Hulubei National Institute for R\&D in Physics and Nuclear Engineering, 30 Reactorului Str. \\ MG-6, Bucharest - Magurele, Romania \\ ${ }^{4}$ Institute of Environmental Geology and Geoengineering of the Italian National Research Council, \\ Rome, Italy, stefano.ubaldini@igag.cnr.it
}

${ }^{\otimes}$ Corresponding author: ipovar@yahoo.ca; Tel.: +373-22-73-97-36; Fax: +373-22-73-97-36

Received: September 27, 2018; Accepted: January 3, 2019

\begin{abstract}
The forms of occurrence of vanadium metal are determined by the major chemical reactions in the aquatic environment such as hydrolysis, oxidation, reduction, and precipitation. Depending on $\mathrm{pH}$, potential and total concentration of inorganic ions and organic ligands, vanadium compounds may undergo various transformations to produce a whole range of chemical forms in aqueous systems. In this paper, a novel approach has been applied for calculating potential-pH (Pourbaix) diagrams, based on the developed thermodynamic analysis of chemical equilibria in the $\mathrm{V}-\mathrm{H}_{2} \mathrm{O}$ system. On the basis of currently revised thermodynamic data for $V(I I I), V(I V)$ and $V(V)$ hydrolysis and original thermodynamic and graphical approach used, the repartition of their soluble and insoluble chemical species has been investigated. By means of $\Delta G-p H$ diagrams, the areas of thermodynamic stability of $V(I V)$ and $V(V)$ hydroxides have been established for a number of analytical concentrations of vanadium in heterogeneous mixtures. The obtained results, based on the thermodynamic analysis and graphic design of calculated data, are in good agreement with available experimental data.
\end{abstract}

\section{Keywords}

Potential-pH diagrams, thermodynamic analysis, thermodynamic stability, vanadium species

\section{Introduction}

Vanadium oxides (V-O) have been widely studied during the last three decades [1-12], mostly due to their broad applications in catalysis and microelectronics. Vanadium is a transition metal with an elevated melting temperature and good corrosion resistance vs. different acids and alkalis at low temperatures. Some alloys containing vanadium are extensively used in car constructions, 
electronics industry, nuclear reactor components and defense technology [13]. Moreover, vanadium catalyst is one of the best catalysts used in chemistry and is also extensively used in the industrial production of sulfuric acid and petroleum refining [14]. In addition, vanadium is used in batteries, electrochemical and fuel cells [15] and ceramic industry [13]. However, the discharge of vanadium and its compounds in environment becomes one of the major causes of pollution. For vanadium, a simultaneous presence of several species in different degrees of oxidation is characteristic and therefore, a number of compounds in the $\mathrm{V}-\mathrm{O}$ system may coexist. This includes oxides $\mathrm{V}_{2} \mathrm{O}_{5}, \mathrm{VO}_{2}, \mathrm{~V}_{2} \mathrm{O}_{3}$, and $\mathrm{VO}$, where vanadium is present in oxidation states $+5,+4,+3$, and +2 , respectively. $V(V)$ species are very toxic and their removal from water has been extensively investigated [16]. Also, $\mathrm{V}(\mathrm{IV})$ and $\mathrm{V}(\mathrm{V})$ species have been defined as particularly toxic in [17]. Many investigations show that toxicity of vanadium and its effect on health depends on its forms and their properties. Therefore, the knowledge of vanadium speciation and its removal from wastewaters is the essential issue in environmental protection.

At the same time, in addition to simple ions, existence of ions containing different number of oxygens in oxyanions is possible. The electron transfer reactions between oxyanions in the aqueous solution are carried out with the participation of hydrogen ions. Consequently, under these conditions, the potential of the electrode would depend on the solution $\mathrm{pH}$. This statement is also true for redox reactions involving solid phases [18]. In order to create the complete picture of thermodynamic properties of elemental compounds in different valence states both in aqueous solution and in solid phases, the potential-pH diagrams, so-called Pourbaix diagrams, have to be used. These diagrams show thermodynamic properties of chemical elements, depending on the $\mathrm{pH}$ and their total concentrations in a solution. Pourbaix diagram is a graphic representation of equilibria in heterogeneous systems containing a solid phase and aqueous solution. With increase in the number of components, polynuclear species appear and calculations of chemical and electrochemical equilibria become considerably complicated. The construction of Pourbaix diagrams in these cases is usually made by calculating potential-pH dependency for various forms of oxidation-reduction pairs [19-21]. This approach sometimes leads to a linear dependence of chemical and electrochemical equilibria on $\mathrm{pH}$ [22]. In these cases, large number of unnecessary lines on the diagram diminishes the amount of information.

The behavior of vanadium in solutions depends on the vanadium concentration, potential and $\mathrm{pH}$ value. Vanadium extraction and its removal from wastewaters have been widely studied in order to decrease vanadium contaminant and employ vanadium sources [23,24]. Despite of large number of experimental data, however, scarce information on thermodynamic properties of vanadium species has been published so far. The original approach of this paper consists in using the thermodynamic method developed by the authors [25] and consistent thermodynamic data for constructions of Pourbaix diagrams for vanadium.

\section{Theoretical}

For constructing Pourbaix diagrams for the vanadium-water system, the standard Gibbs energies of formation $\left(\Delta G_{f}{ }^{0}\right)$ of the vanadium solid and soluble species shown in Table 1 have been used.

The areas of thermodynamic stability of solid phases (oxides), depending on $\mathrm{pH}$ and total concentration of vanadium in the solution, have been initially determined. For this purpose, the Gibbs energy variation of the interaction of the oxide with the aqueous solution components has been calculated. 
Table 1. Standard Gibbs energies of formation for vanadium species at $298.15 \mathrm{~K}$

\begin{tabular}{|c|c|c|c|c|c|}
\hline Species & $\Delta G_{\mathrm{f}}^{0} / \mathrm{kJ} \mathrm{mol}^{-1}$ & Source & Species & $\Delta G_{\mathrm{f}}^{0} / \mathrm{kJ} \mathrm{mol}^{-1}$ & Source \\
\hline $\mathrm{V}^{2+}$ & -218.0 & {$[26]$} & $\mathrm{H}_{2} \mathrm{VO}_{4}^{-}$ & -1023.0 & [31] \\
\hline $\mathrm{VOH}^{+}$ & -467.0 & [27] & $\mathrm{V}_{2} \mathrm{O}_{7}^{4-}$ & -1722.2 & [31] \\
\hline $\mathrm{VO}_{(\mathrm{s})}$ & -402.6 & [28] & $\mathrm{HV}_{2} \mathrm{O}_{7}^{3-}$ & -1778.8 & [31] \\
\hline $\mathrm{V}^{3+}$ & -242.7 & [29] & $\mathrm{H}_{2} \mathrm{~V}_{2} \mathrm{O}_{7}^{2-}$ & -1824.5 & [31] \\
\hline $\mathrm{VOH}^{2+}$ & -418.2 & [27] & $\mathrm{V}_{4} \mathrm{O}_{13}{ }^{6-}$ & -3330.1 & [31] \\
\hline $\mathrm{V}_{2} \mathrm{O}_{3(\mathrm{~s})}$ & -1316.1 & [28] & $\mathrm{HV}_{4} \mathrm{O}_{13}^{5-}$ & -3381.5 & [31] \\
\hline $\mathrm{VO}^{2+}$ & -447.3 & [29] & $\mathrm{V}_{4} \mathrm{O}_{12}{ }^{4-}$ & -3200.2 & [31] \\
\hline $\mathrm{HVO}_{2}^{+}$ & -652.1 & [30] & $\mathrm{V}_{5} \mathrm{O}_{15}{ }^{5-}$ & -3999.5 & [31] \\
\hline $\mathrm{H}_{2} \mathrm{~V}_{2} \mathrm{O}_{4}{ }^{2-}$ & -1330.9 & [30] & $\mathrm{V}_{10} \mathrm{O}_{28}{ }^{6-}$ & 7680.9 & [31] \\
\hline $\mathrm{HV}_{2} \mathrm{O}_{5}^{-}$ & -1491.4 & [30] & $\mathrm{HV}_{10} \mathrm{O}_{28}{ }^{5-}$ & -7715.1 & [31] \\
\hline $\mathrm{V}_{2} \mathrm{O}_{4(\mathrm{~S})}$ & -1316.1 & [28] & $\mathrm{H}_{2} \mathrm{~V}_{10} \mathrm{O}_{28}^{4-}$ & -7736.5 & [31] \\
\hline $\mathrm{VO}_{2}^{+}$ & -588.3 & [29] & $\mathrm{H}_{3} \mathrm{~V}_{10} \mathrm{O}_{28}{ }^{3-}$ & -7745.8 & [31] \\
\hline $\mathrm{HVO}_{4}^{2-}$ & -977.8 & [31] & $\mathrm{V}_{2} \mathrm{O}_{5(\mathrm{~S})}$ & -1421.2 & [28] \\
\hline
\end{tabular}

For the vanadium oxide (V) in aqueous solution, the following dissolution reaction can be written as:

$1 / 2 \mathrm{~V}_{2} \mathrm{O}_{5(\mathrm{~S})}+\mathrm{H}^{+}=\mathrm{VO}_{2}+1 / 2 \mathrm{H}_{2} \mathrm{O}$

The Gibbs energy variation $\left(\Delta G_{r}\right)$ of this reaction is described by the equation of the reaction isotherm:

$$
\Delta G_{r}=\Delta G_{\mathrm{r}}^{0}+R T \ln \frac{c_{V_{2}{ }^{+}}}{C_{\mathrm{H}^{+}}}
$$

where $\Delta G_{f}^{0}$ is the variation of the standard Gibbs energy of the reaction (1):

$$
\Delta G_{r}^{0}=\Delta G_{f}^{0}\left(\mathrm{VO}_{2}{ }^{+}, 298.15 \mathrm{~K}\right)+\frac{1}{2} \Delta G_{\mathrm{f}}{ }^{0}\left(\mathrm{H}_{2} \mathrm{O}, 298.15 \mathrm{~K}\right)-\frac{1}{2} \Delta G_{\mathrm{f}}{ }^{0}\left(\mathrm{~V}_{2} \mathrm{O}_{5(\mathrm{~s})}, 298.15 \mathrm{~K}\right)
$$

Equation (1), however, characterizes the equilibrium in the system $\mathrm{V}_{2} \mathrm{O}_{5(\mathrm{~s})}$ - aqueous solution only in a narrow range of $\mathrm{pH}$ because of various hydrolysis reactions possible in the solution which are listed in Table 2. Equilibrium constants $\left(K_{i}\right)$ of these reactions are calculated based on the data of Table 1, using the well-known thermodynamic relation:

$$
\log K_{\mathrm{i}}=-\frac{\Delta G_{\mathrm{i}}^{0}}{2.3 R T}
$$

Table 2. Possible hydrolysis reactions and their equilibrium constants

\begin{tabular}{cc}
\hline Hydrolysis reaction & $\log K$ \\
\hline $\mathrm{VO}_{2}{ }^{+}+2 \mathrm{H}_{2} \mathrm{O}=\mathrm{H}_{2} \mathrm{VO}_{4}{ }^{-}+2 \mathrm{H}^{+}$ & $\log K_{1}=-6.96$ \\
$\mathrm{VO}_{2}{ }^{+}+2 \mathrm{H}_{2} \mathrm{O}=\mathrm{HVO}_{4}{ }^{2-}+3 \mathrm{H}^{+}$ & $\log K_{2}=-14.88$ \\
$\mathrm{VO}_{2}{ }^{+}+2 \mathrm{H}_{2} \mathrm{O}=\mathrm{VO}_{4}{ }^{3-}+4 \mathrm{H}^{+}$ & $\log K_{3}=-29.14$ \\
$2 \mathrm{VO}_{2}{ }^{+}+3 \mathrm{H}_{2} \mathrm{O}=\mathrm{V}_{2} \mathrm{O}_{7}^{4-}+6 \mathrm{H}^{+}$ & $\log K_{4}=-29.09$ \\
$2 \mathrm{VO}_{2}^{+}+3 \mathrm{H}_{2} \mathrm{O}=\mathrm{HV}_{2} \mathrm{O}^{3-}+5 \mathrm{H}^{+}$ & $\log K_{5}=-19.17$ \\
$2 \mathrm{VO}_{2}{ }^{+}+3 \mathrm{H}_{2} \mathrm{O}=\mathrm{H}_{2} \mathrm{~V}_{2} \mathrm{O}_{7}{ }^{2-}+4 \mathrm{H}^{+}$ & $\log K_{6}=-11.15$ \\
$4 \mathrm{VO}_{2}{ }^{+}+5 \mathrm{H}_{2} \mathrm{O}=\mathrm{V}_{4} \mathrm{O}_{13}{ }^{6-}+10 \mathrm{H}^{+}$ & $\log K_{7}=-36.72$ \\
$4 \mathrm{VO}_{2}{ }^{+}+5 \mathrm{H}_{2} \mathrm{O}=\mathrm{HV}_{4} \mathrm{O}_{13}{ }^{5-}+9 \mathrm{H}^{+}$ & $\log K_{8}=-27.62$ \\
$4 \mathrm{VO}_{2}{ }^{+}+4 \mathrm{H}_{2} \mathrm{O}=\mathrm{V}_{4} \mathrm{O}_{12}{ }^{4-}+8 \mathrm{H}^{+}$ & $\log K_{9}=-17.84$ \\
$5 \mathrm{VO}_{2}{ }^{+}+5 \mathrm{H}_{2} \mathrm{O}=\mathrm{V}_{5} \mathrm{O}_{15}{ }^{5-}+10 \mathrm{H}^{+}$ & $\log K_{10}=-22.42$ \\
$10 \mathrm{VO}_{2}{ }^{+}+8 \mathrm{H}_{2} \mathrm{O}=\mathrm{V}_{10} \mathrm{O}_{28}{ }^{6-}+16 \mathrm{H}^{+}$ & $\log K_{11}=-17.47$ \\
$10 \mathrm{VO}_{2}{ }^{+}+8 \mathrm{H}_{2} \mathrm{O}=\mathrm{HV}_{10} \mathrm{O}_{28}{ }^{5-}+15 \mathrm{H}^{+}$ & $\log K_{12}=-11.47$ \\
$10 \mathrm{VO}_{2}{ }^{+}+8 \mathrm{H}_{2} \mathrm{O}=\mathrm{H}_{2} \mathrm{~V}_{10} \mathrm{O}_{28}{ }^{4-}+14 \mathrm{H}^{+}$ & $\log K_{13}=-7.73$ \\
$10 \mathrm{VO}_{2}{ }^{+}+8 \mathrm{H}_{2} \mathrm{O}=\mathrm{H}_{3} \mathrm{~V}_{10} \mathrm{O}_{28}{ }^{3-}+13 \mathrm{H}^{+}$ & $\log K_{14}=-6.10$
\end{tabular}


Evidence of the influence of hydrolysis reactions on the equilibrium reaction (1) leads to the following expression for $\Delta G_{\mathrm{r}}[25]$ :

$$
\Delta G_{\mathrm{r}}=\Delta G_{r}^{0}-R T \ln \alpha_{\mathrm{VO}_{2}^{+}}-R T \ln c_{\mathrm{H}}+R T \ln c_{\mathrm{V}}
$$

In eq. (5), $c_{V}$ denotes the total concentration of $V(V)$ in solution, while $\alpha \mathrm{vo}_{2}{ }^{+}$is the coefficient which takes into account contributions of hydrolysis reactions listed in Table 2, and is described by the expression

$$
\begin{aligned}
& \alpha_{V_{2} 2^{+}}=1+K_{1} C_{H^{2}}+K_{2} C_{H^{-3}}+K_{3} C_{H^{-4}}+2 c_{V} K_{4} C_{H^{-6}}+2 C_{V} K_{5} C_{H^{-5}}+2 C_{V} K_{6} C_{H^{-4}}+4 c_{V}{ }^{3} K_{7} C_{H^{-10}}+4 c_{V}^{3} K_{8} C_{H}^{-9}+ \\
& +4 c_{\mathrm{V}}{ }^{3} K_{9} C_{H^{-8}}+5 c_{\mathrm{V}}{ }^{4} K_{10} C_{H^{-10}}+10 c_{\mathrm{V}}{ }^{9} K_{11} C_{H^{-16}}+10 c_{v}{ }^{9} K_{12} C_{H^{-15}}+10 c_{v}{ }^{9} K_{13} C_{H^{-14}}+10 c_{v}{ }^{9} K_{14} C_{H^{-13}}
\end{aligned}
$$

where $\mathrm{CVO}_{2}{ }^{+}$is the equilibrium concentration of the $\mathrm{VO}_{2}{ }^{+}$ion, determined for a given $\mathrm{pH}$ value under the mass balance conditions:

$$
c_{\mathrm{v}}=\sum_{\mathrm{i}} \sum_{\mathrm{j}} \sum_{\mathrm{n}} j c_{\mathrm{H}_{\mathrm{i}} \mathrm{O}_{\mathrm{n}}}=c_{\mathrm{vO}_{2}{ }^{+}} \alpha_{\mathrm{vO}_{2}{ }^{+}}
$$

The calculations can be performed by well-known numerical methods using the software for real solutions of the system of nonlinear equations.

\section{Results and discussion}

Results of calculations of the $\Delta G_{\mathrm{r}}-\mathrm{pH}$ dependence using eq. (5) for several $c_{V}$ values are shown in Figure 1. Within the used thermodynamic approach, the solid phase is stable for $\Delta G_{\mathrm{r}}<0$, and dissolves for $\Delta G_{r}>0$. Therefore, the condition $\Delta G_{r}=0$ corresponds to the equilibrium of the solid phase with aqueous solution. One can see from Figure 1 that vanadium oxide $(\mathrm{V})$ is stable in a narrow range of low $\mathrm{pH}$ values, while for $\mathrm{CV}_{\mathrm{V}}<10^{-2} \mathrm{~mol} \mathrm{~L}^{-1}, \mathrm{~V}_{2} \mathrm{O}_{5(\mathrm{~s})}$ does not precipitate at all. Thermodynamic stability areas of other vanadium oxides are determined analogously.

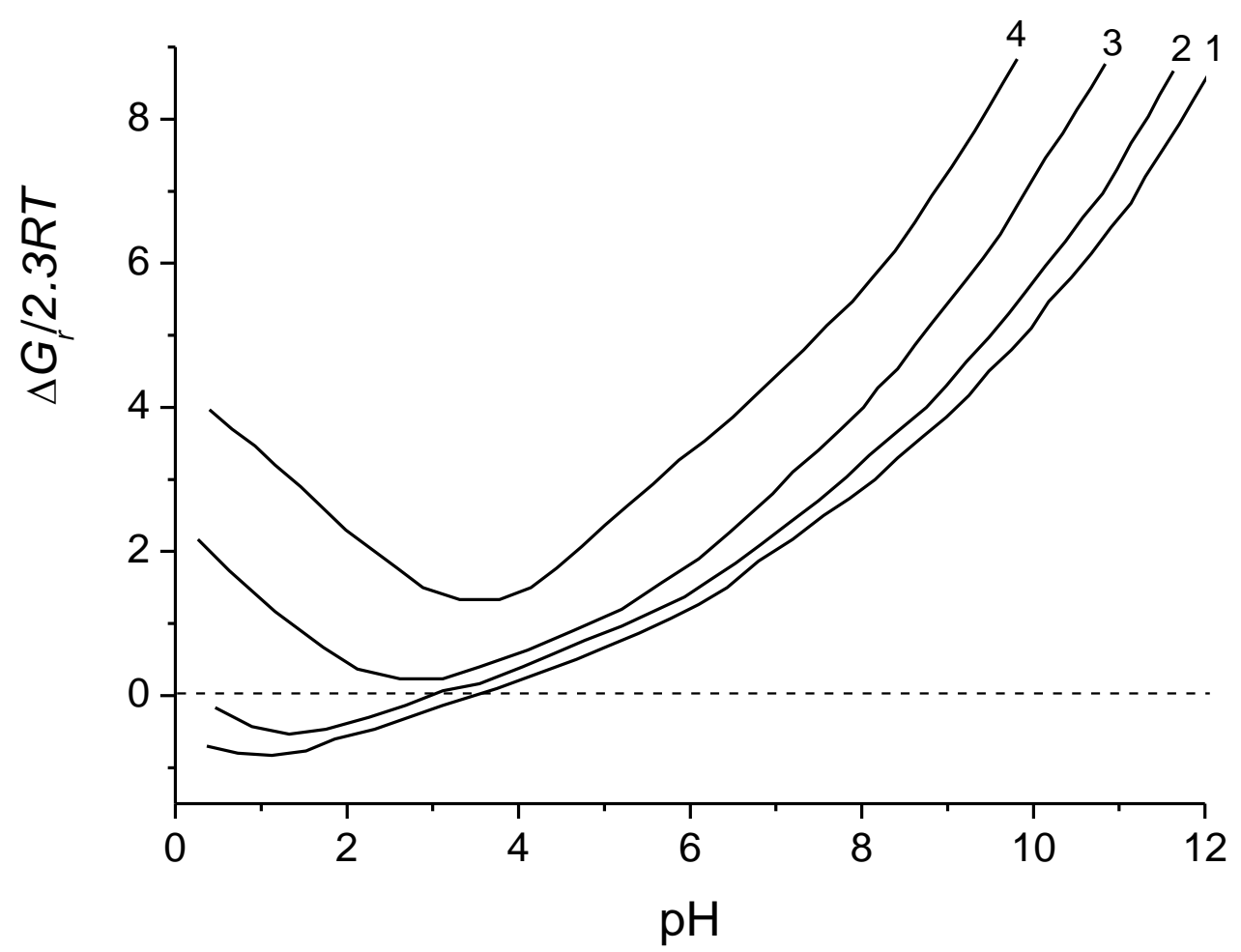

Figure 1. Dependence of $\Delta \mathrm{G}_{r}$ on $\mathrm{pH}$ for reaction (1), taking into account hydrolysis reactions and $\mathrm{c}_{\mathrm{V}}$ : 1 - $1 \mathrm{~mol} \mathrm{~L}^{-1} ; 2$ - $10^{-1} \mathrm{~mol} \mathrm{~L}^{-1} ; \mathbf{3}-10^{-3} \mathrm{~mol} \mathrm{~L}^{-1} ; 4-10^{-5} \mathrm{~mol} \mathrm{~L}^{-1}$ 
Within the $\mathrm{pH}$ range where the solid phase (oxide) is thermodynamically unstable (dissolves), it is necessary to determine the areas of predominance of the species in solution. In the presence of polynuclear species, it is useful to calculate the partial molar fractions of the species as functions of $\mathrm{pH}$ and $c_{v}$. For vanadium compounds $(\mathrm{V})$ for example, partial molar fractions are determined in the following way [32]:

$$
f_{\mathrm{ijn}}=\frac{j c_{\mathrm{H}_{\mathrm{i}} \mathrm{v}_{\mathrm{n}}}}{\sum_{\mathrm{i}} \sum_{\mathrm{j}} \sum_{\mathrm{n}} j c_{\mathrm{H}_{\mathrm{i}} \mathrm{O}_{\mathrm{n}}}}
$$

The calculation results of these functions for $V(V)$ compounds and $c_{V}=10^{-3} \mathrm{~mol} \mathrm{~L}^{-1}$ as functions of $\mathrm{pH}$ are shown in Figure 2. Based on these calculations, it is easy to determine the thermodynamic stability of vanadium species in the solution as a function of $\mathrm{pH}$ and $\mathrm{cv}$.
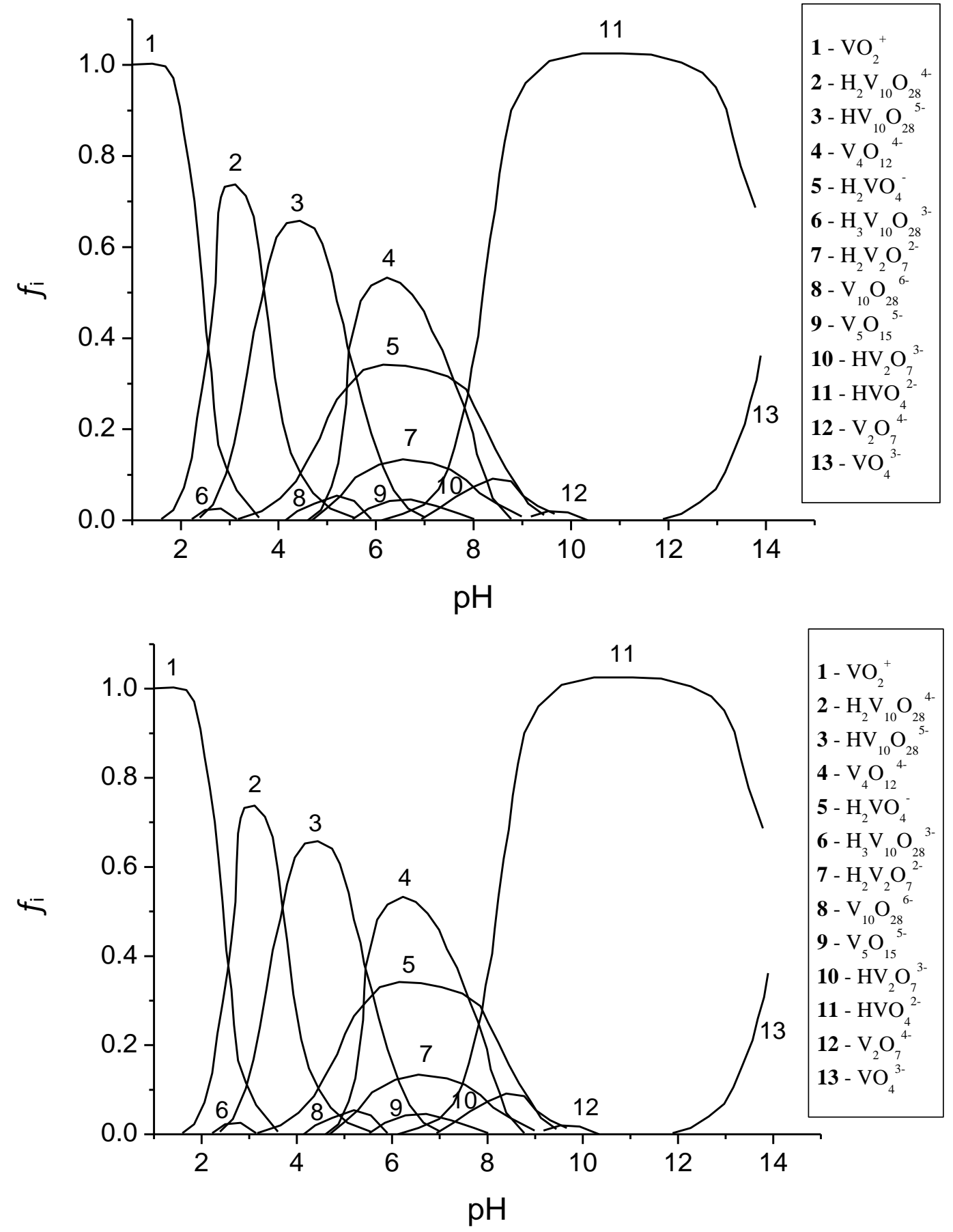

Figure 2. Partial molar fractions of vanadium (V) species for $\mathrm{c}_{V}=10^{-3} \mathrm{~mol} \mathrm{~L}^{-1}$ 
By establishing the thermodynamic stability areas of both solid and soluble phases, one can calculate the $\mathrm{pH}$ dependence of $\Delta G_{\mathrm{r}}$ or $E$ for different redox pairs.

Here, $V(V) \rightarrow V(I V)$ reduction as a function of $\mathrm{pH}$ for $c_{V(V)}=c_{V(I V)}=10^{-3} \mathrm{~mol} \mathrm{~L}^{-1}$ is examined as the example. The areas of thermodynamic stability of $\mathrm{V}(\mathrm{V})$ and $\mathrm{V}(\mathrm{IV})$ species under these conditions are shown in Table 3.

Table 3. $\mathrm{pH}$ areas of thermodynamic stability of $V(V)$ and $V(I V)$ species for $\mathrm{C}_{V(V)}=\mathrm{C}_{V(I V)}=10^{-3} \mathrm{~mol}^{-1}$

\begin{tabular}{cccc}
\hline $\mathrm{V}(\mathrm{V})$ & $\mathrm{pH}$ area & $\mathrm{V}(\mathrm{IV})$ & $\mathrm{pH}$ area \\
\hline $\mathrm{VO}_{2}^{+}$ & $0 \leq 2.7$ & $\mathrm{VO}^{2+}$ & $0 \leq 3.7$ \\
$\mathrm{H}_{2} \mathrm{~V}_{10} \mathrm{O}_{28}{ }^{4-}$ & $2.7 \leq 3.8$ & $\mathrm{~V}_{2} \mathrm{O}_{4(\mathrm{~S})}$ & $3.7 \leq 8.2$ \\
$\mathrm{HV}_{10} \mathrm{O}_{28}{ }^{5-}$ & $3.8 \leq 5.5$ & $\mathrm{HV}_{2} \mathrm{O}_{5}$ & $8.2 \leq 14.0$ \\
$\mathrm{~V}_{4} \mathrm{O}_{12}{ }^{4-}$ & $5.5 \leq 7.9$ & & \\
$\mathrm{H}_{2} \mathrm{VO}_{4}^{-}$ & $7.9 \leq 8.0$ & & \\
$\mathrm{HVO}_{4}{ }^{-}$ & $8.0 \leq 14.0$ & & \\
\hline
\end{tabular}

Therefore, the reduction reaction of $\mathrm{V}(\mathrm{V})$ to $\mathrm{V}(\mathrm{IV})$ versus $\mathrm{pH}$ can be described by following eight equations:

$$
\begin{array}{ll}
\mathrm{VO}_{2}^{+}+2 \mathrm{H}^{+}+\mathrm{e}^{-}=\mathrm{VO}^{2+}+\mathrm{H}_{2} \mathrm{O} & 0 \leq \mathrm{pH} \leq 2.7 \\
(1 / 10) \mathrm{H}_{2} \mathrm{~V}_{10} \mathrm{O}_{28} 4^{-}+(17 / 5) \mathrm{H}^{+}+\mathrm{e}^{-}=\mathrm{VO}^{2+}+(9 / 5) \mathrm{H}_{2} \mathrm{O} & 2.7 \leq \mathrm{pH} \leq 3.7 \\
(1 / 10) \mathrm{H}_{2} \mathrm{~V}_{10} \mathrm{O}_{28}{ }^{4-}+(7 / 5) \mathrm{H}^{+}+\mathrm{e}^{-}=(1 / 2) \mathrm{V}_{2} \mathrm{O}_{4(\mathrm{~S})}+(4 / 5) \mathrm{H}_{2} \mathrm{O} & 3.7 \leq \mathrm{pH} \leq 3.8 \\
(1 / 10) \mathrm{HV}_{10} \mathrm{O}_{28} 5^{5-}+(3 / 2) \mathrm{H}^{+}+\mathrm{e}^{-}=(1 / 2) \mathrm{V}_{2} \mathrm{O}_{4(\mathrm{~S})}+(4 / 5) \mathrm{H}_{2} \mathrm{O} & 3.8 \leq \mathrm{pH} \leq 5 \\
(1 / 4) \mathrm{V}_{4} \mathrm{O}_{12} 4^{4-}+2 \mathrm{H}^{+}+\mathrm{e}^{-}=(1 / 2) \mathrm{V}_{2} \mathrm{O}_{4(\mathrm{~S})}+\mathrm{H}_{2} \mathrm{O} & 5.5 \leq \mathrm{pH} \leq 7.9 \\
\mathrm{H}_{2} \mathrm{VO}_{4}^{-}+2 \mathrm{H}^{+}+\mathrm{e}^{-}=(1 / 2) \mathrm{V}_{2} \mathrm{O}_{4(\mathrm{~S})}+2 \mathrm{H}_{2} \mathrm{O} & 7.9 \leq \mathrm{pH} \leq 8.0 \\
\mathrm{HVO}_{4}{ }^{2-}+3 \mathrm{H}^{+}+\mathrm{e}^{-}=(1 / 2) \mathrm{V}_{2} \mathrm{O}_{4(\mathrm{~S})}+2 \mathrm{H}_{2} \mathrm{O} & 8.0 \leq \mathrm{pH} \leq 8.2 \\
\mathrm{HVO}_{4}{ }^{2-}+(5 / 2) \mathrm{H}^{+}+\mathrm{e}^{-}=(1 / 2) \mathrm{HV}_{2} \mathrm{O}_{5}+(3 / 2) \mathrm{H}_{2} \mathrm{O} & 8.2 \leq \mathrm{pH} \leq 14.0
\end{array}
$$

On the basis of these data, the $\mathrm{V}(\mathrm{V})-\mathrm{V}(\mathrm{IV})$ redox potentials $\left(E_{\mathrm{i}}\right)$ are described by means of Nernst equations for $\left(C_{V}(\mathrm{~V})=C_{V}(\mathrm{IV})=10^{-3} \mathrm{~mol} \mathrm{~L}^{-1}\right)$ :

$$
\begin{aligned}
& E_{1}=E_{1}^{0}-(R T / F) \ln C_{H^{-2}} \\
& E_{2}=E_{2}^{0}-(R T / F) \ln C_{H^{-17.5} C^{-9 / 10}} \\
& E_{3}=E_{3}^{0}-(R T / F) \ln C_{H^{-7.5} C V^{-1 / 10}} \\
& E_{4}=E_{4}^{0}-(R T / F) \ln C_{H^{-3 / 2} C V^{-1 / 10}} \\
& E_{5}=E_{5}^{0}-(R T / F) \ln C_{H^{-2} C V^{-1 / 4}} \\
& E_{6}=E_{6}^{0}-(R T / F) \ln C_{H^{-2} C V^{-1}} \\
& E_{7}=E_{7}^{0}-(R T / F) \ln C_{H^{-3} C V^{-1}} \\
& E_{8}=E_{8}{ }^{0}-(R T / F) \ln C_{H^{-5 / 2} C V^{-0.5}}
\end{aligned}
$$

where $E_{i}^{0}$ denotes standard redox potential.

Final potential-pH diagrams for vanadium species at total concentrations of all soluble species equal to $1,10^{-3}$ and $10^{-5} \mathrm{~mol} \mathrm{~L}^{-1}$ are shown in Figure 3 .

As one can see, the presence of polynuclear species in the system makes impossible the presentation of potential - $\mathrm{pH}$ diagrams for different $c_{V}$ in the single figure. This is explained by the fact that variation of $c_{V}$ changes not only thermodynamic stability areas, but also the composition of predominant species. Thus, with the decrease of $\mathrm{V}(\mathrm{V})$ concentration, the stability of polynuclear species is diminished. At the same time, at low values of $c V$, vanadium oxide $(V)$ becomes thermodynamically unstable. 
a

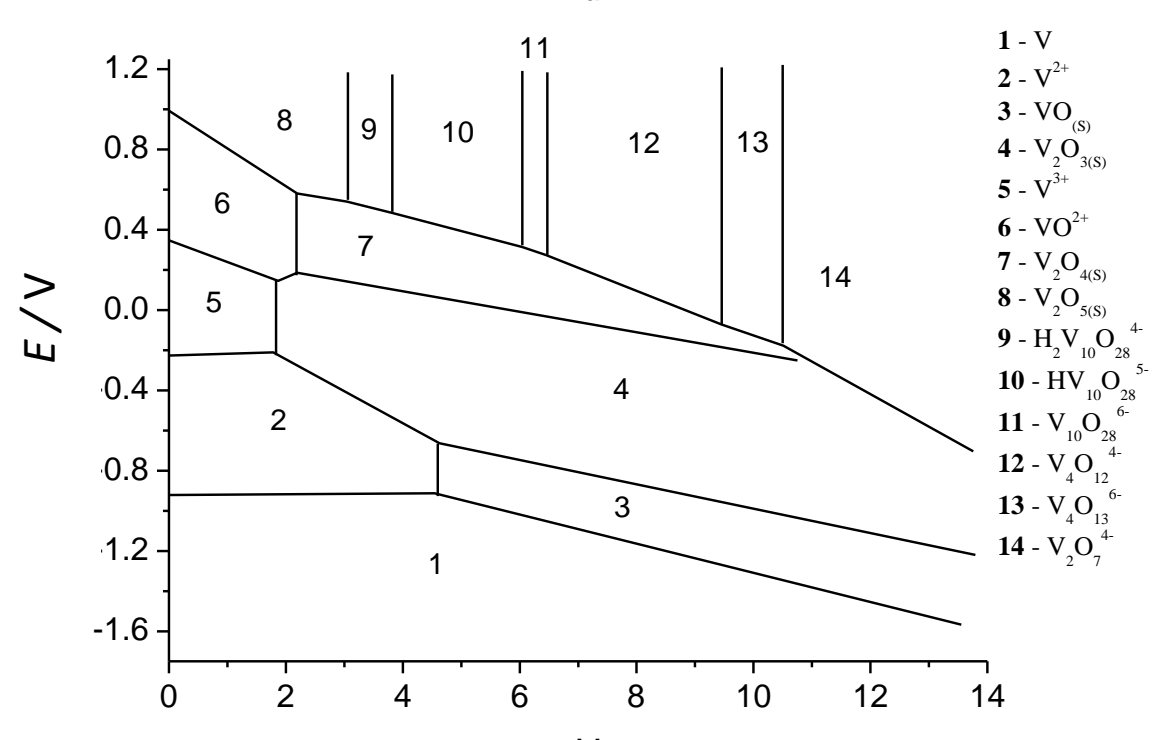

b

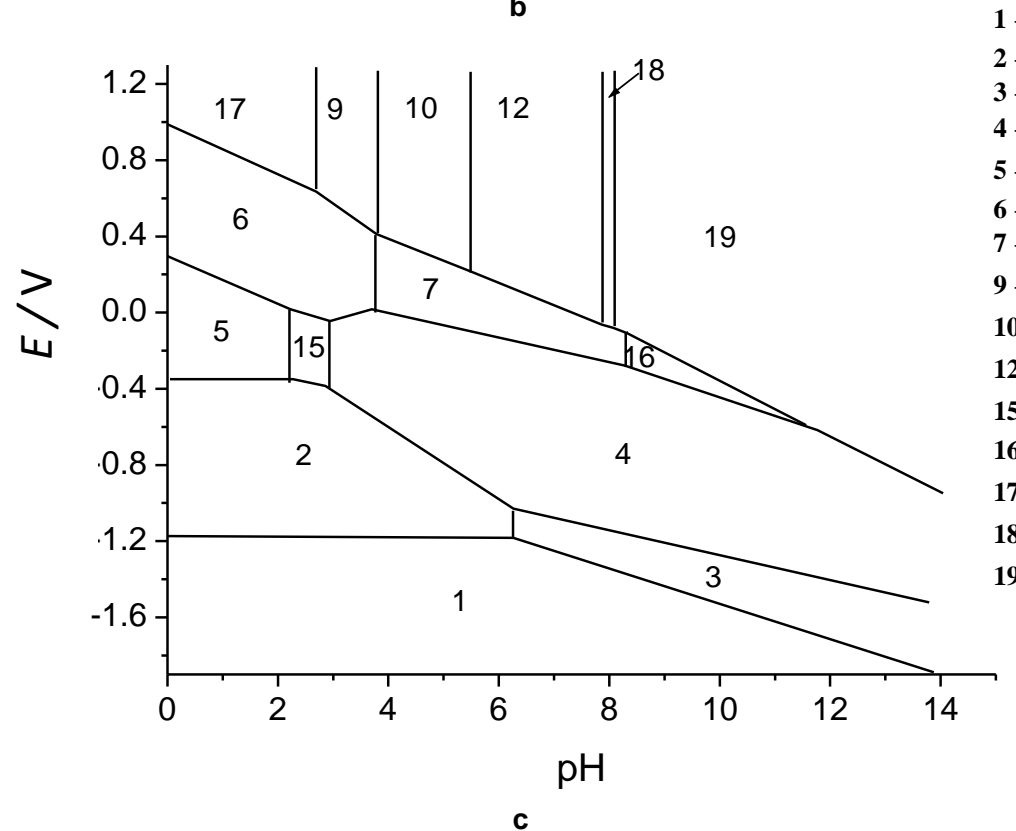

$1-\mathrm{V}$

$2-\mathrm{V}^{2+}$

3 $-\mathrm{VO}_{(\mathrm{S})}$

$4-\mathrm{V}_{2} \mathrm{O}_{3(\mathrm{~S})}$

$5-\mathrm{V}^{3+}$

$6-\mathrm{VO}^{2+}$

$7-\mathrm{V}_{2} \mathrm{O}_{4(\mathrm{~S})}$

$9-\mathrm{H}_{2} \mathrm{~V}_{10} \mathrm{O}_{28}{ }^{4}$ $10-\mathrm{HV}_{10} \mathrm{O}_{28}$ $12-\mathrm{V}_{4} \mathrm{O}_{12}^{4-}$ $15-\mathrm{VOH}^{2+}$ $16-\mathrm{HV}_{2} \mathrm{O}_{5}^{-}$ $17-\mathrm{VO}_{2}^{+}$ $18-\mathrm{H}_{2} \mathrm{VO}_{4}$ $19-\mathrm{HVO}_{4}^{2-}$

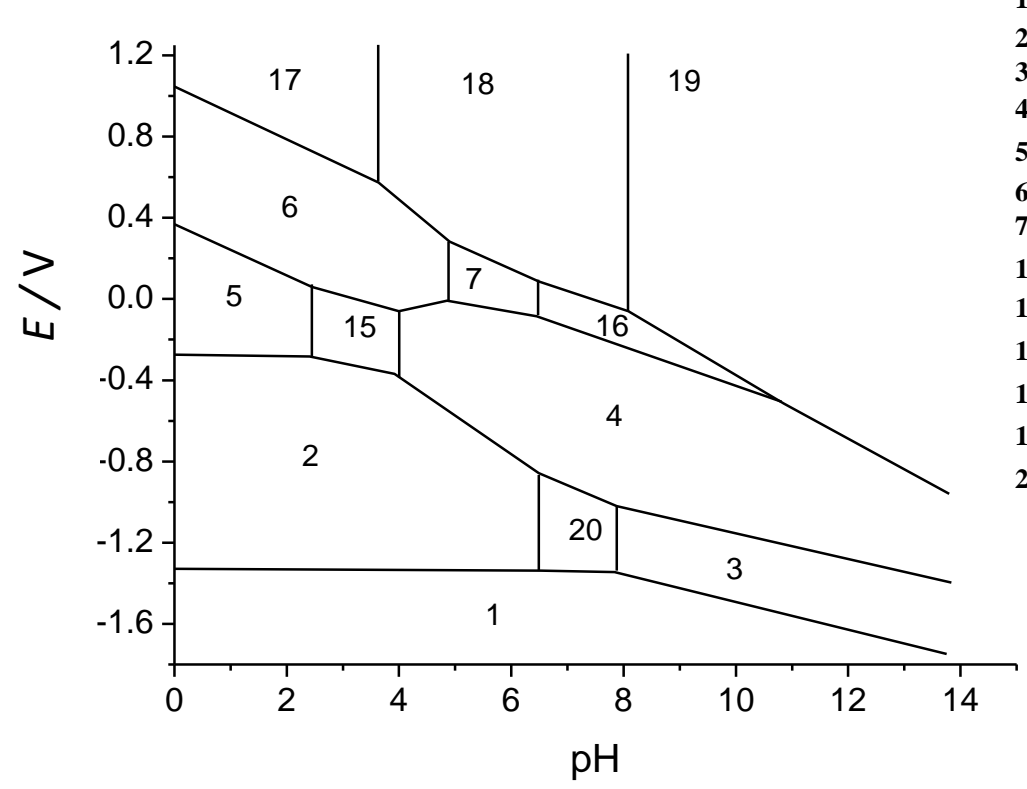

$1-\mathrm{V}$

$2-\mathrm{V}^{2+}$

$3-\mathrm{VO}_{(\mathrm{S})}$

$4-\mathrm{V}_{2} \mathrm{O}_{3(\mathrm{~S})}$

$5-\mathrm{V}^{3+}$

$6-\mathrm{VO}^{2+}$

$7-\mathrm{V}_{2} \mathrm{O}_{4(\mathrm{~S})}$

$15-\mathrm{VOH}^{2+}$

$16-\mathrm{HV}_{2} \mathrm{O}_{5}$ $17-\mathrm{VO}_{2}^{+}$ $18-\mathrm{H}_{2} \mathrm{VO}_{4}$ 19- $\mathrm{HVO}_{4}^{2-}$ $20-\mathrm{VOH}^{+}$

Figure 3. Potential-pH diagrams for vanadium species and $\mathrm{c}_{V}: \boldsymbol{a}-1 \mathrm{~mol} L^{-1}, \boldsymbol{b}-10^{-3} \mathrm{~mol} \mathrm{~L} L^{-1}, \boldsymbol{c}-10^{-5} \mathrm{~mol} \mathrm{~L} L^{-1}$ 
A particular feature of vanadium chemistry is that $V(I V)$ species in alkaline medium are simultaneously oxidized and reduced to $V(V)$ and $V(I I I)$ species. In the diagram, this is manifested by the fact that the range of potentials where V(IV) species are thermodynamically stable becomes narrowed with the $\mathrm{pH}$ increase.

In calculating potential-pH diagrams in the general case, $E(\mathrm{pH})$ (or $\Delta G_{\mathrm{r}}(\mathrm{pH})$ ) functions are approximated by a system of linear-discontinued functions. In the presence of mononuclear species in the system, this approximation is quite justified [33,34]. It is interesting to elucidate whether this approximation can be justified in the presence of polynuclear species, because in such a case, areas of predominance of species in solution are insufficiently distinct. Thus, for $\mathrm{cV}_{\mathrm{V}}=10^{-3} \mathrm{~mol} \mathrm{~L}^{-1}$ and $\mathrm{pH}$ $6, \mathrm{~V}(\mathrm{~V}) \rightarrow \mathrm{V}(\mathrm{IV})$ transformation within the linear approximation is described by the following equation:

$$
1 / 4 \mathrm{~V}_{4} \mathrm{O}_{12}{ }^{4-}+2 \mathrm{H}^{+}+\mathrm{e}=1 / 2 \mathrm{~V}_{2} \mathrm{O}_{4(\mathrm{~S})}+\mathrm{H}_{2} \mathrm{O}
$$

At $\mathrm{pH} 6$ value, $\mathrm{V}_{4} \mathrm{O}_{12}{ }^{4-}$ ions predominate, but as shown in Figure 2, other species are also present in the solution. The calculations show that partial molar fractions in this particular case are:

$$
f_{\mathrm{HVO}_{4}{ }^{2}}=0.01, f_{\mathrm{H}_{2} \mathrm{VO}_{4}}=0.33, \quad f_{\mathrm{H}_{2} \mathrm{~V}_{2} \mathrm{O}_{7}{ }^{2}}=0.13, \quad f_{\mathrm{V}_{4} \mathrm{O}_{12}{ }^{4-}}=0.48, \quad f_{\mathrm{V}_{5} \mathrm{O}_{15}{ }^{5}}=0.05
$$

Therefore, at $\mathrm{pH} 6$ and $\mathrm{cV}_{\mathrm{V}}=10^{-3} \mathrm{~mol} \mathrm{~L}^{-1}$, the transformation $\mathrm{V}(\mathrm{V}) \rightarrow \mathrm{V}(\mathrm{IV})$ is more correctly described by the following system of equations:

$$
\begin{array}{lr}
\mathrm{HVO}_{4}{ }^{2-}+3 \mathrm{H}^{+}+\mathrm{e}^{-}=(1 / 2) \mathrm{V}_{2} \mathrm{O}_{4(\mathrm{~S})}+2 \mathrm{H}_{2} \mathrm{O} & 1 \% \\
\mathrm{H}_{2} \mathrm{VO}_{4}{ }^{-}+2 \mathrm{H}^{+}+\mathrm{e}^{-}=(1 / 2) \mathrm{V}_{2} \mathrm{O}_{4(\mathrm{~S})}+2 \mathrm{H}_{2} \mathrm{O} & 33 \% \\
(1 / 2) \mathrm{H}_{2} \mathrm{~V}_{2} \mathrm{O}_{7}{ }^{2-}+2 \mathrm{H}^{+}+\mathrm{e}^{-}=(1 / 2) \mathrm{V}_{2} \mathrm{O}_{4(\mathrm{~S})}+(3 / 2) \mathrm{H}_{2} \mathrm{O} & 13 \% \\
(1 / 4) \mathrm{V}_{4} \mathrm{O}_{12}{ }^{4-}+2 \mathrm{H}^{+}+\mathrm{e}^{-}=(1 / 2) \mathrm{V}_{2} \mathrm{O}_{4(\mathrm{~S})}+\mathrm{H}_{2} \mathrm{O} & 48 \% \\
(1 / 5) \mathrm{V}_{5} \mathrm{O}_{15}{ }^{5-}+2 \mathrm{H}^{+}+\mathrm{e}^{-}=(1 / 2) \mathrm{V}_{2} \mathrm{O}_{4(\mathrm{~S})}+\mathrm{H}_{2} \mathrm{O} & 5 \%
\end{array}
$$

where next to each equation, the contribution of the respective equilibrium reaction is presented in fractions, \%.

The results of the $\mathrm{V}(\mathrm{V})-\mathrm{V}(\mathrm{IV})$ pair calculation in a small $\mathrm{pH}$ range for $\mathrm{c}_{\mathrm{V}}=10^{-3} \mathrm{~mol} \mathrm{~L}^{-1}$, obtained by both the exact equation and linear approximation, are shown in Table 4 . The linear approximation approach was developed in [35]. In above mentioned example, instead of all the equilibria (9), the most predominant equilibrium with the $48 \%$ contribution is taken into account.

Table 4. $\mathrm{pH}$ dependence of the electrode potential of the pair vanadium (V)/vanadium (IV) for $\mathrm{c}_{V}=1 \times 10^{-3} \mathrm{~mol} \mathrm{~L}^{-1} ; 1$ - exact calculation; 2 - calculation in linear approximation.

\begin{tabular}{ccccccc}
\hline & $\mathrm{pH}$ & 4 & 5 & 6 & 7 & 8 \\
\hline 1 & $E / \mathrm{V}$ & 0.411 & 0.322 & 0.219 & 0.100 & -0.004 \\
2 & $E / \mathrm{V}$ & 0.418 & 0.329 & 0.233 & 0.115 & 0.007 \\
\hline
\end{tabular}

\section{Conclusions}

1. On the basis of thermodynamic data, the area of thermodynamic stability of vanadium chemical species as a function of $\mathrm{pH}$ for each degree of oxidation has been determined.

2. System of electrochemical equations for electrode reactions between chemical species in different degrees of oxidation and overlapped predominance areas has been derived. Also, the dependence $\Delta G_{\mathrm{r}}$ or $E$ on $\mathrm{pH}$ is calculated for different redox pairs.

3. Depending on $\mathrm{pH}, \mathrm{p} E$ (-log $E$ ), and total concentration of inorganic ligands, vanadium compounds may undergo various transformations to produce a whole range of chemical species in solution. 
$E-\mathrm{pH}$ diagrams of the $\mathrm{V}-\mathrm{H}_{2} \mathrm{O}$ systems have been constructed, showing well agreement with previously reported experimental data.

4. It has been proved that the calculation of the $E(\mathrm{pH})$ in linear approximation by a system of linear - discontinued functions in the presence of polynuclear species is fully acceptable.

Acknowledgements: This work was partially supported by the National Research Council of Italy [grant number SAC.AD002.015.013] and Academy of Sciences of Moldova [grant number 18.80013.5007.01/it].

\section{References}

[1] E. Hryha, E. Rutqvist, L. Nyborg, Surface and Interface Analysis 44 (2012) 1022-1025. http://dx.doi.org/10.1002/sia.3844

[2] S. Youn, S. Jeong, D. H. Kim, Catalysis Today 232 (2014) 185-191. http://dx.doi.org/10.1016/i.cattod.2014.01.025

[3] G. Beamson, N. Moslemzadeh, P. Weightman, J. F. Watts. Journal of Electron Spectroscopy and Related Phenomena, 162 (2008) 19-24. http://dx.doi.org/10.1016/i.elspec.2007.08.001

[4] N. F. Quackenbush, H. Paik, J. C. Woicik, D. A. Arena, D. G. Schlom, L. F. Piper, Materials 8 (2015) 54525466. http://dx.doi.org/10.3390/ma8085255

[5] H. Qiu, M. Yang, Y. Dong, H. Xu, B. Hong, Y. Gu, C. Gao, New Journal of Physics 17 (2015) 113016. http://dx.doi.org/10.1088/1367-2630/17/11/113016

[6] K. Miyazaki, K. Shibuya, M. Suzuki, H. Wado, A. Sawa, Journal of Applied Physics 118 (2015) 055301. http://dx.doi.org/10.1063/1.4927746

[7] F. Ureña-Begara, A. Crunteanu, J. P. Raskin, Applied Surface Science 403 (2017) 717-727. http://dx.doi.org/10.1016/i.apsusc.2017.01.160

[8] C. Zhang, Q. Yang, C. Koughia, F. Ye, M. Sanayei, S. J. Wen, S. Kasap, Thin Solid Films, 620 (2016) 64-69. http://dx.doi.org/10.1016/j.tsf.2016.07.082

[9] X. Zhang, H. Schwarz, Chemistry-A European Journal 16 (2010) 1163-1167. http://dx.doi.org/10.1002/chem.200902810

[10] A. Majjane, A. Chahine, M. Et-tabirou, B. Echchahed, T. O. Do, P. Mc Breen, Materials Chemistry and Physics 143 (2014) 779-787. http://dx.doi.org/10.1016/j.matchemphys.2013.10.013

[11] M. Demeter, M. Neuman, W. Reichelt, Surface Science 454 (2000) 41-44. http://dx.doi.org/10.1016/S0039-6028(00)00111-4

[12] D. Rehder, Dalton Transactions 42 (2013) 11749-11761. http://dx.doi.org/10.1039/C3DT50457C

[13] S. L. Radchenko, Y. S. Radchenko, Glass and Ceramics 7 (2016) 270-273.

[14] A. Akcil, F. Vegliò, F. Ferella, M. D. Okudan, A. Tuncuk, Waste Management 45 (2015) 420-433. http://dx.doi.org/10.1016/i.wasman.2015.07.007

[15] Y. Yan, Y. Li, M. Skyllas-Kazacos, J. Bao, Journal of Power Sources 322 (2016) 116-128. http://dx.doi.org/10.1016/i.jpowsour.2016.05.011

[16] T. R. S. Cadaval Jr, G. L. Dotto, E. R. Seus, N. Mirlean, L. A. de Almeida Pinto, Desalination and Water Treatment 57 (2016) 16583-16591. http://dx.doi.org/10.1080/19443994.2015.1079741

[17] Y. Wang, X. Yin, H. Sun, C. Wang, Chemical Speciation \& Bioavailability 28 (2016) 7-12. http://dx.doi.org/10.1080/09542299.2015.1133238

[18] I. Fishtik, I. Povar, Canadian Journal of Chemistry, 84 (2016) 1036-1044. https://doi.org/10.1139/v06-127

[19] G. M. Voldman, A. N. Zelikman, The theory of hydrometallurgical processes, Intermet Engineering, Moscow, Russia, 2003, 464 p. (in Russian)

[20] R. R. Salem, Physical chemistry Beginning (Theoretical Electrochemistry), University book, Moscow, Russia, 2001, 326 p. (in Russian)

[21] K. L. Nash, G. R. Choppin, Separation Science and Technology 32 (1997) 255-274. https://doi.org/10.1080/01496399708003198

[22] I. F. Fishtik, I. I. Vataman, Thermodynamics of hydrolysis of metal ions, Stiinta, Chisinau, Republic of Moldova, 1988, 393 p. (in Russian)

[23] H. I. Gomes, A. Jones, M. Rogerson, G. M. Greenway, D. F. Lisbona, I. T. Burke, W. M. Mayes, Journal of Environmental Management 187 (2017) 384-392. http://dx.doi.org/10.1016/i.jenvman.2016.10.063 
[24] H. Y. Li, K. Wang, W. H. Hua, Z. Yang, W. Zhou, B. Xie, Hydrometallurgy 160 (2016) 18-25. http://dx.doi.org/10.1016/i.hydromet.2015.11.014

[25] I. Povar, O. Spinu, Journal of Electrochemical Science and Engineering 6 (2016) 145-153. https://doi.org/10.5599/jese.229

[26] A. M. Sukhotina, Ed., Handbook of Electrochemistry, Chemistry, Leningrad, Soviet Union, 1981, 448 p. (in Russian)

[27] C. F. Baes, R. E. Mesmer, The Hydrolysis of Cations, Wiley Interscience, N.Y., USA, 1976, 489 p.

[28] V. P. Glushko, Ed., Thermal constants of substances, Publishing House of the USSR Academy of Sciences, Moscow, Soviet Union, 1965-1982, Vol. 1-10. (in Russian)

[29] V. V. Vasiliev. Thermodynamic properties of solutions of electrolytes, Higher School, Moscow, Soviet Union, 1982, 320 p. (in Russian)

[30] N. Takeno, Atlas of Eh-pH diagrams. Geological survey of Japan open file report 419 (2005) 102, 285 p.

[31] L. Pettersson, B. Hedman, I. Andersson, N. Ingri, Chemica Scripta 22 (1983) 254-264.

[32] M. Beck, I. Nadipal, Investigation of complexation by the latest methods, Mir, Moscow, Soviet Union, 1989, 411 p. (in Russian)

[33] I. F. Fishtik, I. G. Povar, I. I. Vataman, $10^{\text {th }}$ International Congress on metal corrosion, Madras, India, 1987, 56-57.

[34] V. Sjoberg, K. Todd, L. Sartz, S. Karlsson, $11^{\text {th }}$ International Mine Water Association Congress - Mine Water-Managing the Challenges, Aachen, Germany, 2011, 481-484.

[35] I. Fishtik, I. Povar, Koordinatsionnaya Khimiya 17 (1991) 17-20.

(C)2019 by the authors; licensee IAPC, Zagreb, Croatia. This article is an open-access article distributed under the terms and conditions of the Creative Commons Attribution license (http://creativecommons. org/licenses/by/4.0/) 